\title{
Community training in dishwashing-liquid soap making from waste cooking oil
}

\author{
Evelyn (iD) *, Edy Saputra (D), Komalasari, Syelvia Putri Utami \\ Department of Chemical Engineering, Engineering Faculty, Universitas Riau
}

* evelyn@eng.unri.ac.id

\begin{abstract}
Cooking oil that has been used more than once is not good for health due to exposure to carcinogens. Waste cooking oil causes pollution to the environment. Waste cooking oil can be used as a raw material for making liquid soap. The objective of this activity was to introduce the knowledge and train Batu Basurat community in making dishwashing-liquid soap from waste cooking oil. The method consists of location survey, training preparation, interactive training, monitoring, and evaluation. Dishwashing-liquid soap was made by mixing preheated waste cooking oil and potassium hydroxide $(\mathrm{KOH})$ at $60-70$ ${ }^{\circ} \mathrm{C}$ for one hour until trace was formed. Then, the mixture was kept agitated every 15 minutes for 2-3 hours until it becomes more solidified and transparent. Liquid soap was made by dissolving in warm water and addition of lemon essence as a deodorizer. Batu Basurat villagers showed a great interest in the activity, showing by enthusiasm and involvement in the training. Evaluation results showed that $100 \%$ community understood on making homemade dishwashing-liquid soap and $90 \%$ community agreed that liquid soap from waste cooking oil has a commercial potential, which could increase entrepreneurship ability and economic growth of Batu Bersurat villagers.
\end{abstract}

\begin{abstract}
Abstrak Minyak jelantah adalah minyak goreng yang telah digunakan lebih dari satu kali penggorengan. Konsumsi minyak jelantah berdampak tidak baik bagi kesehatan karena mengandung zat karsinogen. Limbah minyak jelantah adalah polutan bagi lingkungan. Minyak jelantah dapat dipakai sebagai bahan baku pembuatan sabun cair. Tujuan kegiatan ini adalah untuk mengenalkan dan melatih keterampilan pembuatan sabun cair dari minyak jelantah pada desa Batu Bersurat, Kabupaten Kampar Riau. Metode yang digunakan meliputi survei lokasi, persiapan pelatihan, pelatihan interaktif, serta monitoring dan evaluasi. Pembuatan sabun cair dilakukan dengan mencampur minyak jelantah dengan larutan potassium hidroksida $(\mathrm{KOH})$ pada suhu $60-70{ }^{\circ} \mathrm{C}$ dan diaduk selama satu jam sampai larutan mengental (trace). Setelah pendiaman selama 15 menit, campuran terus diaduk setiap 15 menit selama 2-3 jam sampai lebih mengental dan berwarna transparan. Terakhir, campuran siap ditambahkan dengan lemon essence sebagai pewangi. Terlihat antusias masyarakat yang cukup besar pada pelatihan pembuatan sabun cair, yang ditunjukkan oleh keterlibatan masyarakat pada saat demontrasi. Hasil evaluasi menunjukkan $100 \%$ masyarakat paham mengenai cara pembuatan sabun cair dari minyak jelantah dan $90 \%$ setuju bahwa pemanfaatan kembali minyak jelantah menjadi sabun cair mempunyai potensi komersil yang dapat mendorong kemampuan wirausaha dan pertumbuhan ekonomi masyarakat tempatan.
\end{abstract}

Keywords: triglyceride; alkali; glycerol; saponification; entrepreneurship

\section{ठ OPEN ACCESS}

Citation: Evelyn, E. Saputra, Komalasari, and S.P. Utami. 2018. Community training in dishwashing-liquid soap making from waste cooking oil. Riau Journal of Empowerment 1(2): 67-74 https://doi.org/10.31258/raje.1.2.9

Received: 2018-10-22, Revised: 2018-11-14 Accepted: 2018-11-17

Language: English (en)

Funding: This community service activity was funded by Lembaga Penelitian dan Pengabdian kepada Masyarakat Universitas Riau year 2018

C 2018 Evelyn et al. The article by Author(s) is licensed under a Creative Commons Attribution 4.0 International License. This license permits unrestricted use, distribution, and reproduction in any medium, provided the original author and source are credited. 


\section{INTRODUCTION}

Batu Basurat village is located not far $( \pm 1 \mathrm{Km})$ from Koto Panjang Hydroelectric Power Plant. It is also located around $5 \mathrm{Km}$ from Budha relics temple, Muara Takus. The lands are mainly hills with a large amount of softpeat soils. The village is led by a head village with the help of one secretary and four section chiefs. Majority of people are ethnic Melayu Ocu that firmly hold the traditional customs. The people are also very open to visitors and new knowledge since this community was newcomers in Batu Basurat region.

The total number of people living in Batu Basurat village is 2721 people or 722 families. Most of the people work as farmers, plantation workers (rubber and oil palm), livestock workers, with some others have no permanent jobs (621 people). Figure 1 shows the job distribution of people in the village. The community's economy is not as good as people who have also moved from the power plant region to other regions. This is due to not all of the replacement lands supplied by the government have good fertility and located quite far from the houses. About 429 families are categorized poor, with the income of $\pm \mathrm{Rp} 1.500 .000$ per month. A total of 667 from 722 families regularly obtain rice for the poor villagers from the government.
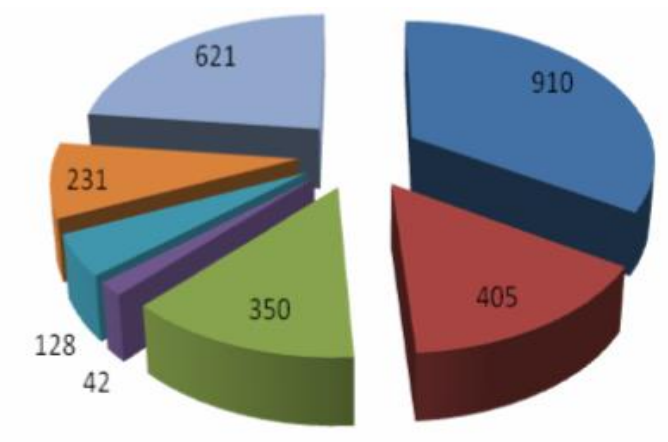

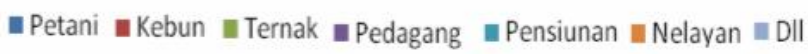

Figure 1. Job distribution of people in Batu Basurat village

In average, each house consumes between 2 and $4 \mathrm{~L}$ of cooking oil in a month (Suriyani, 2016). Many people living in Batu Basurat indicates a lot of consumption of cooking oil. The price of cooking oil is not cheap; hence, many people choose to buy waste cooking oil or using the oil for more than one time. Waste or dark cooking oil is not good for health, since this cooking oil may produce carcinogens during the processes. Dark cooking oil could ruin people's health, causing cancer and consequently reducing intelligence of the next generation (Anonim, 2012; Arini, 2014). Therefore, there is a need to introduce the knowledge and correctly handle the waste to avoid losses, i.e. diseases as well as the pollutant to the environment, for example by re-utilizing the oil to make useful products.

Waste cooking oil can be processed to produce liquid soaps for washing dishes. The processes are a combination of chemical reaction and heating. Soap is an alkali substance that lowers water's surface tension thus having the ability to clean clothes, etc. (Naomi et al., 2013). Not only for household consumption, but dishwashing-liquid soap can also be utilized as commercialized goods to increase the income of the community. Therefore, it is important to introduce and train the villagers of Batu Bersurat Kecamatan XIII Koto Kampar, Kabupaten Kampar Riau, in making dishwashing-liquid soap from waste cooking oil through demonstration and discussions.

\section{PROBLEMS}

Quality of cooking oil decreases after used (more than once). The decline in the quality of cooking oil can be seen from the dark color observed, strong bad odor, and impurities contained. Waste cooking oil has often been thrown away to the environment that resulted in (land and water) pollution. Several investigators have used waste cooking oil to make fuel such as biodiesel. Waste cooking oil can also be used to make soap using developed process 
technology (Nevin and Sweeney, 2013), by reacting with the alkali such as potassium or sodium hydroxide ( $\mathrm{KOH}$ or $\mathrm{NaOH})$. A wide variety of vegetable wastes can also be applied to make solid or liquid soaps. Therefore, there is a need to share knowledge of soap making from waste cooking oil to Batu Basurat villagers since these people lived in a new region and categorized poor, so they can use the knowledge to fulfill daily needs or commercialize the product (hence, improving the income).

\section{METHOD}

\section{Stages in Community Training}

The community training for dishwashing-liquid soap making was divided into several stages. Firstly, selection of the target community or survey at the beginning of July 2018 was carried out. After the village of Batu Basurat Kampar was selected, coordination with the head of the village as well as Universitas Riau (UNRI) students who were doing their community service program $(\mathrm{KKN})$ was made, to decide the time for training. This activity was in parallel with materials preparation for the soap making. Next, attempts were made in Chemical Engineering laboratory UNRI to make dishwashing-liquid soap from waste cooking oil until the best procedure was established (with the help of two Chemical Engineering students also involved in the village training). Powerpoint presentation slides, leaflets, and banner were subsequently made for the training. Both activities were performed between 9 to 17 July 2018. Then, training of dishwashing-liquid soap making was held on 20 of July 2018. The training started with an introduction between UNRI's team and Batu Basurat villagers and head, followed by the presentation of the materials, leaflets distribution, demonstration, and discussions.

\section{Procedure for Making Dishwashing-Liquid Soap}

There were two steps used in the dishwashing-liquid soap making: purification of waste cooking oil and saponification. In the purification, $1 \mathrm{~kg}$ of waste cooking oil was filtered to separate the impurities, followed by incorporating $100 \mathrm{~g}$ of activated charcoal powder into the oil for $10 \mathrm{~min}$ (bleaching). The oil was then re-filtered again to obtain a clear oil. Temperature and mixing have been shown to increase (saponification) reaction rates (Levenspiel, 1987). Saponification was carried out by preparation of $300 \mathrm{ml}$ cleared oil sample and $\mathrm{KOH}$ solution (30 $\mathrm{g}$ of $\mathrm{KOH}$ in $100 \mathrm{ml}$ aquades), heating of the oil and $\mathrm{KOH}$ solution at $60-70{ }^{\circ} \mathrm{C}$ separately followed by mixing the two components for $\pm 1 \mathrm{hr}$ at $60-70{ }^{\circ} \mathrm{C}$ until trace was formed, leaving the trace unmixed for 15 minutes until formation of two layers (the upper layer was the soap and the bottom layer was glycerin), mixing every 15 minutes for 2-3 hours until the mixture become more solidified and has a transparent color, addition of lemon essence as a deodorizer, obtaining the liquid soap by dissolving $100 \mathrm{~g}$ of the solid mixture into $250 \mathrm{ml}$ warm water, and finally collection of clear solution of dishwashing-liquid soap in plastic bottles.

\section{Monitoring and Evaluation}

Monitoring and evaluation of the activity or topic delivered in the form of questionnaires were carried out to investigate the community responses. This activity was carried out between 10 and 24 August 2018. A total of 50 questionnaires were sent and filled by the Batu Basurat villagers. The results were then compiled and the final report was made.

\section{DISCUSSION}

\section{Village Condition}

Batu Basurat village is quite far from Pekanbaru, the capital city of Riau province. This village can only be reached by car or public transportation in about $2.5 \mathrm{hrs}$. Despite this, it was easy to find the area with good accessibility from Riau-Sumbar main road. Its far location from the city provides villagers a challenge to fulfill their needs. Although the majority of people work as farmers who are supported by wide available area, good weather, and livestock animals, however, some people seemed reluctant to do farming due to lack of knowledge (lack of 
educated people), minimum funding, and long distance from the lands. Thus, many people have a monthly income per capita less than Rp. 1.500.000.

The high population density of Batu Basurat and due to the fondness for eating boiled foods than fried foods resulted in high consumption of cooking oil. Average weekly consumption or growth rate of cooking and other frying oil of $8.32 \%$ (2011-2015) was recorded and was estimated to increase in 2018 (Ministry of Agriculture, 2015). Dark cooking oil left over is the pollutant to the environment, and if use for more than two one or two times is dangerous for health. Therefore, many efforts have been done to utilize waste cooking oil, among them is to produce dishwashing-liquid soap. Liquid soap has been known to be more expensive than solid soap and is difficult to find in the village.

\section{Community Training}

The goals for community training in dishwashing-liquid soap making are to:

1. describe the bad effects of waste cooking oil to people and the environment.

2. increase the community's knowledge and skills about dishwashing-liquid soap making from waste (cooking) oil.

3. do community service as one of Tri Dharma Perguruan Tinggi.
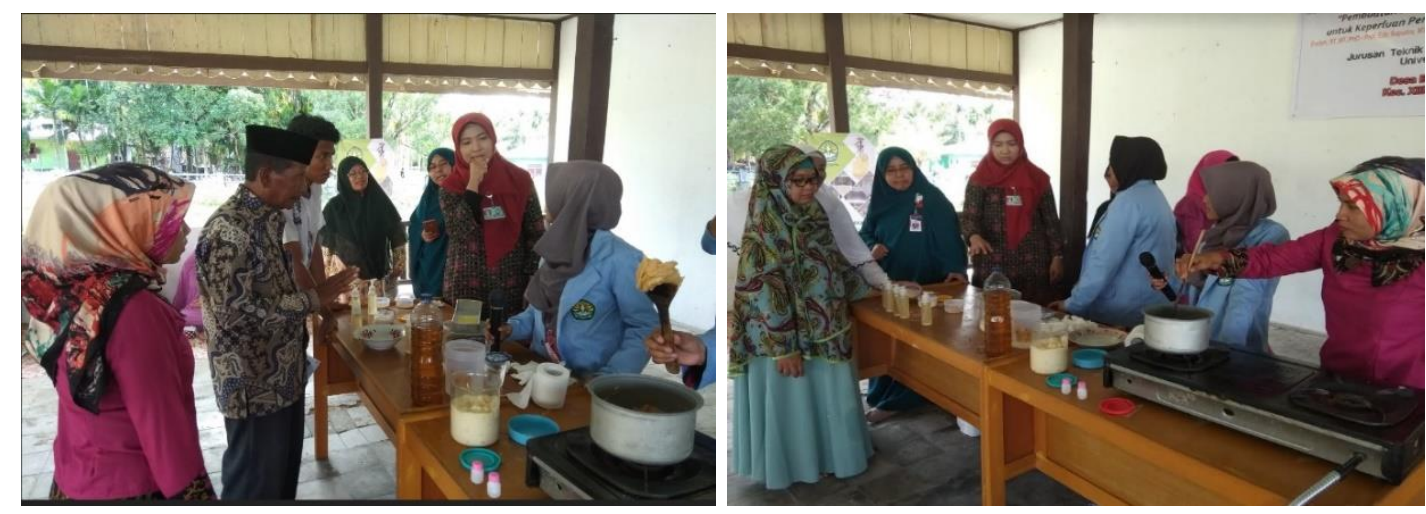

Figure 2. Demonstration on dishwashing-liquid soap making from waste cooking oil to Batu Basurat villagers with the help of two Chemical Engineering students.
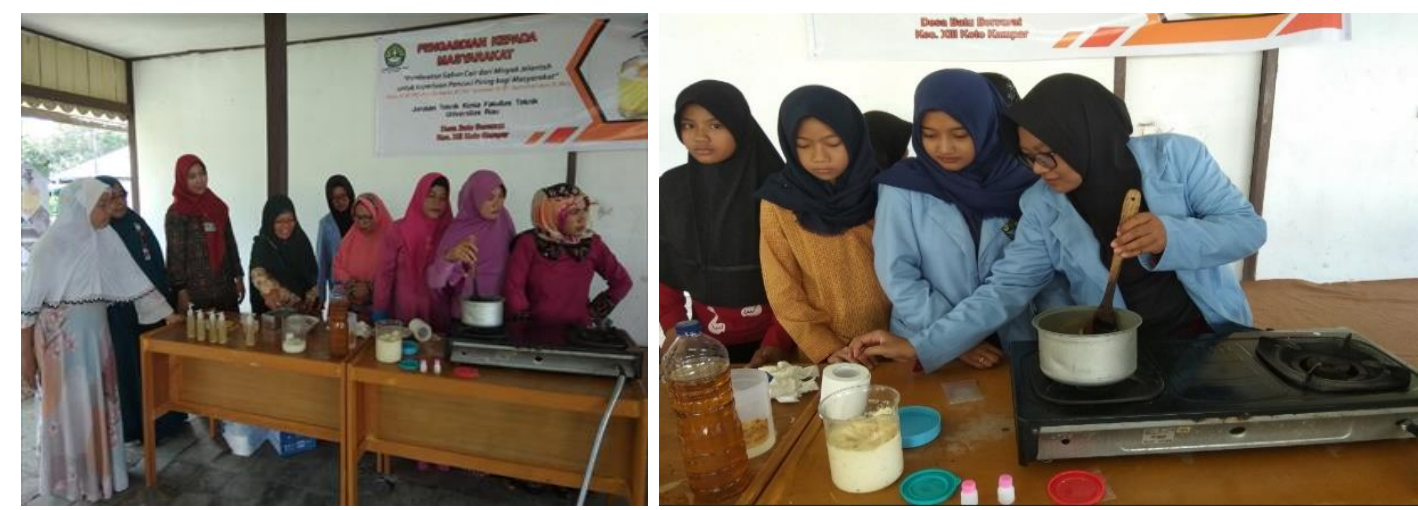

Figure 3. The enthusiasm showed by Batu Basurat villagers and UNRI community service program students on dishwashing-liquid soap making from waste cooking oil.

After welcoming ceremonial from Batu Basurat villagers and opening speeches from both parties, the training was started with powerpoint presentation followed by demonstration. The Batu Basurat villagers consist of the village head, village government officials, elderlies, family welfare empowerment women, and UNRI community service program students. Figure 2 shows the demonstration and discussion activities on dishwashing-liquid soap making from waste cooking oil to Batu Basurat community with the support of two Chemical Engineering students (Figures 3 and 4). It can be seen that the community showed a great interest and 
enthusiasm in the topic delivered. Some of the villagers were also actively involved in the training (Figures 2 and 3). Positive responses from the villagers can also be seen during questions and answers section, and enthusiasm in receiving samples of raw materials provided by the UNRI team. Figure 4 also shows the distribution of ready-use dishwashing-liquid soap from UNRI team to the Batu Basurat village head. Leaflets and banner were also exposed to the community during the training for easier topic understanding and facilitate the people in replicating the soap-production process (Figures 5 and 6).
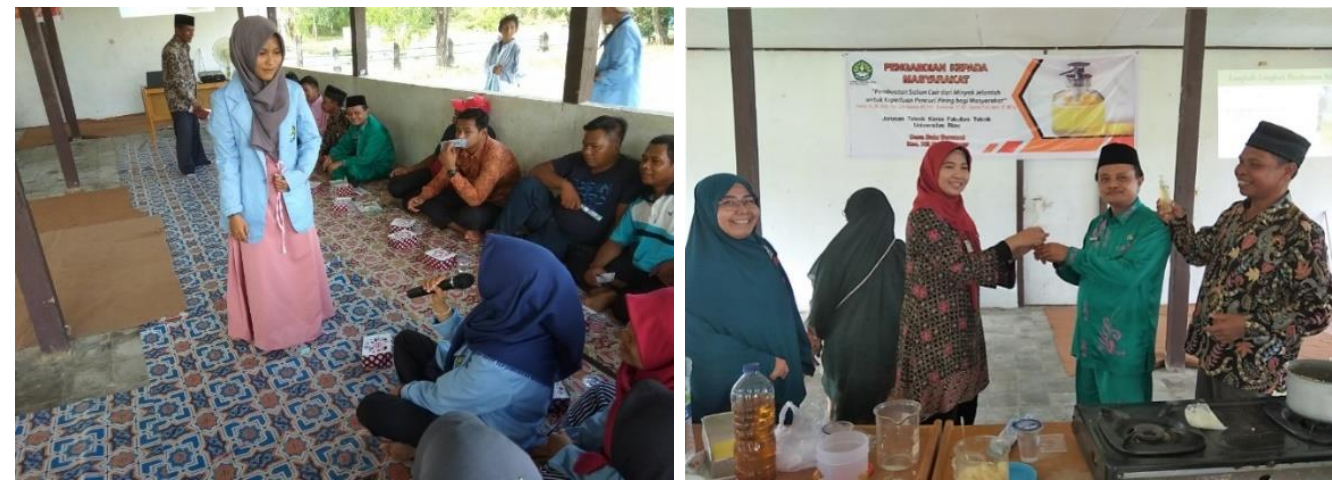

Figure 4. Discussions section of dishwashing-liquid soap making from waste cooking oil and liquid soap sample distribution to the head of Batu Basurat village.

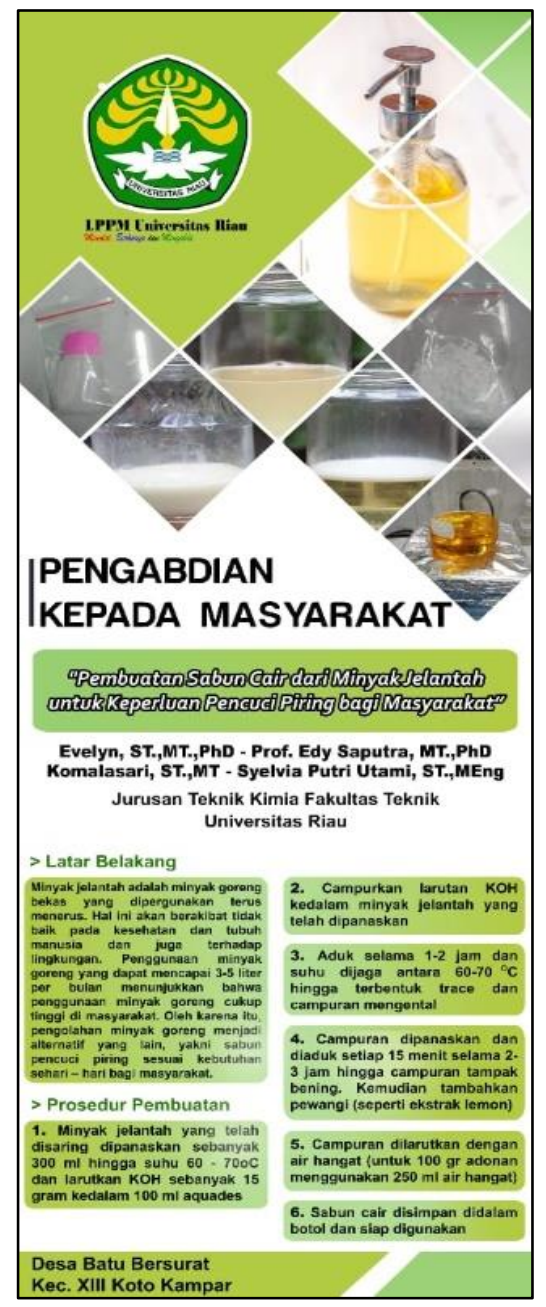

Figure 5. Banner used in the Batu Basurat community training on dishwashing-liquid soap making from waste cooking oil 
There were inhibiting and supporting factors that appeared from the training. Regarding the inhibiting factors, the villagers concerned about getting the chemical, i.e. $\mathrm{KOH}$, which is sold in certain places only. Despite the reason, the people were still showing a great interest in utilizing waste cooking oil to make dishwashing-liquid soap at home or independently. With respect to the supporting factors, full supports from the elderlies and village head were seen. For example, by inviting the people lived in the area to gather at the village meeting hall for the training on the 20th of July 2018. Village head expected that the training could increase the knowledge of the community, so the people could be more open, modern, and independent. In addition, the participation of the community service program students as master of ceremony and audiences were other supporting factors, as shown by the enthusiasm in the topic delivered during the training.

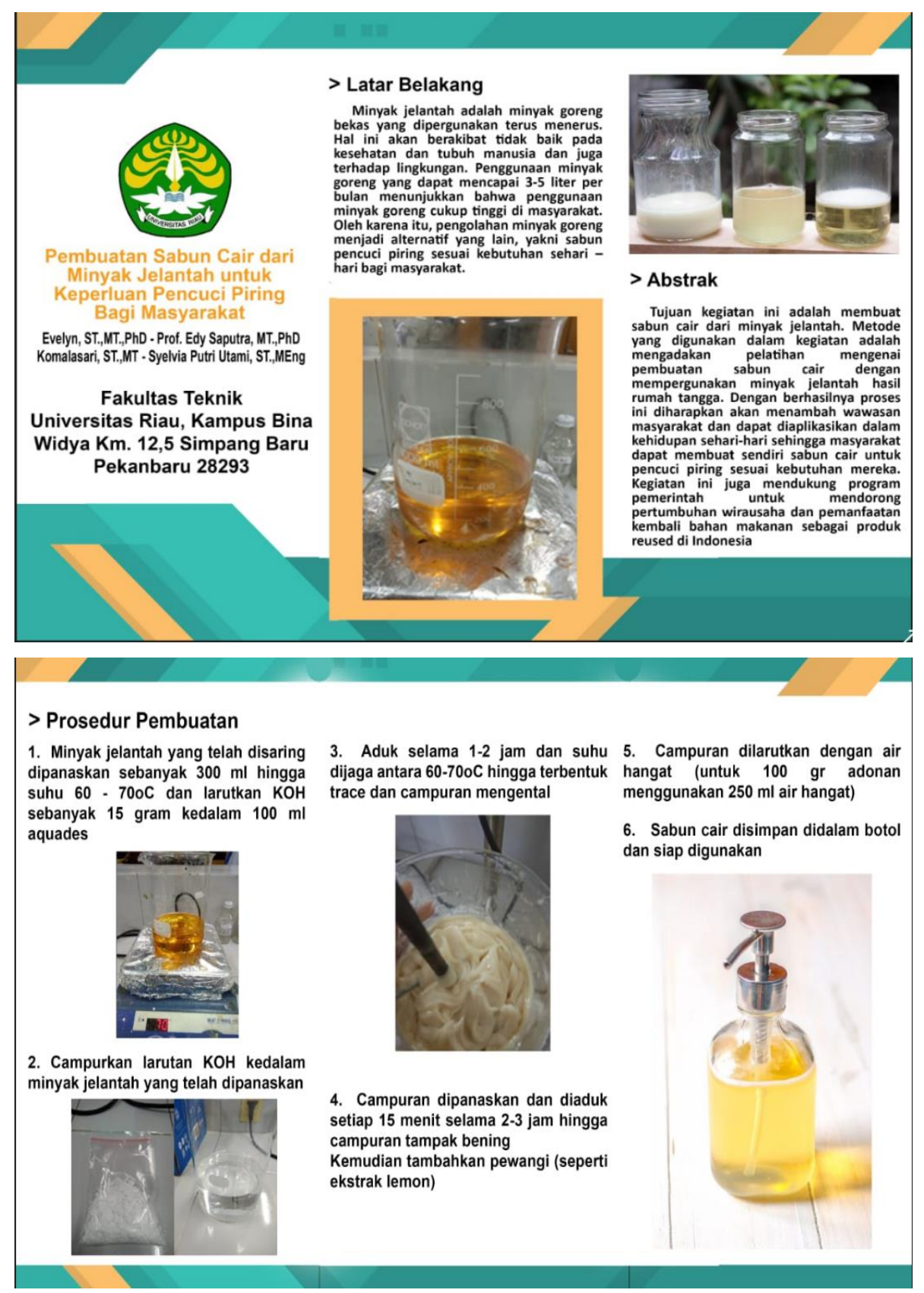

Figure 6. Leaflets used in the Batu Basurat community training on dishwashing-liquid soap making from waste cooking oil 


\section{Monitoring and Evaluation Results}

Evelyn et al.

Figure 7 shows the monitoring and evaluation results on community understanding of dishwashing-liquid soap making through 50 questionnaires made. Surveys indicate that all respondents $(100 \%)$ from the training were able to understand the process of making dishwashing-liquid soap from waste cooking oil explained by UNRI team. Among these respondents, $73 \%$ of respondents practiced the liquid-soap making at home or their neighborhood (Figure 7a). 67\% people did not find any difficulties in replicating the process ( $33 \%$ found obstacles such as difficulty in finding $\mathrm{KOH}$ ) (Figure $7 \mathrm{~b}$ ). Nonetheless, the obstacles experienced did not decrease the community interest in this activity $(88 \%$, Figure $7 \mathrm{c})$. The interest was supported by commercial potential of dishwashing-liquid soap from waste cooking oil which later on could support the economic growth of Batu Basurat village people (90\% respondents) (Figure 7d). The results from questionnaires also revealed that the villagers would like to have several topics in future community training delivered by UNRI team, these include animal feed production and composting.

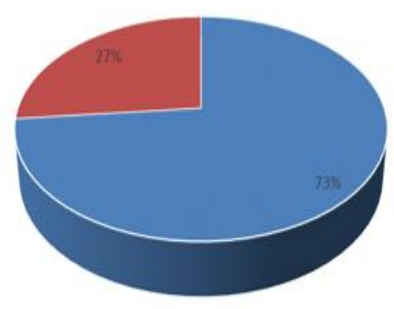

(a)

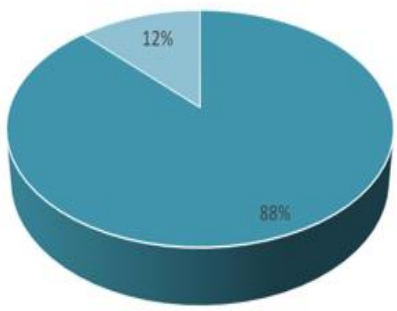

(c)

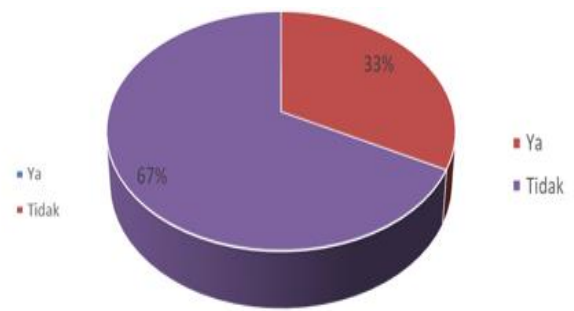

(b)

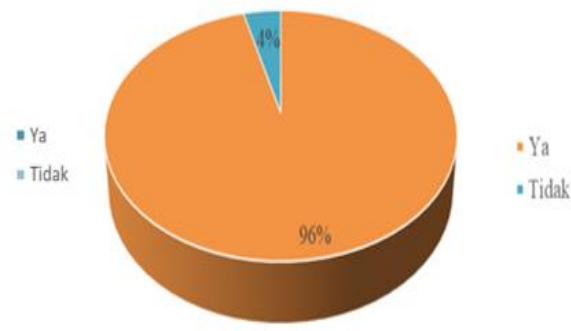

(d)

Figure 7. Number of respondents/audiences who: practicing dishwashing-liquid soap making independently (a), did not find any obstacles in the dishwashing-liquid soap making (b), willing to practice the dishwashing-liquid soap making despite the obstacles (c) and, have the opinion that dishwashing-liquid soap from waste cooking oil has commercial potential (d)

\section{CONCLUSION}

Training on dishwashing-liquid soap making from waste cooking oil was carried out for Batu Basurat villagers and UNRI community service program students on the 20th of July 2018. The community exhibited a great interest in utilizing waste cooking oil as a raw material to produce the dishwashing-liquid soap, showing by the enthusiasm in the training and evaluation's results. One obstacle faced by the villagers was obtaining the chemical $(\mathrm{KOH})$. In the future, this obstacle could probably be overcome by finding the replacement of $\mathrm{KOH}$ from natural sources. For the next step, the villagers should be motivated to form smallsynergized groups that can run business in liquid-soap production from waste cooking oil.

\section{ACKNOWLEDGEMENT}

Authors would like to thank Lembaga Penelitian dan Pengabdian kepada Masyarakat Universitas Riau for the community service grant 2018 awarded. Hospitality of Batu Basurat villagers and the help from Universitas Riau community service program students are also appreciated. 


\section{References}

1. Anonim. 2012. Bahaya Menggunakan Minyak Jelantah. Smallcrab.com: http://www.smallcrab.com/kesehatan/1184-bahaya-menggunakan-minyak-jelantah Accessed 5 March 2015.

2. Arini, W.D. 2014. Pengaruh Kecepatan Sentrifugasi Terhadap Kemurnian Gliserol Sebagai Hasil Samping Pembuatan Biodiesel dari Minyak Goreng Bekas. Undergraduate Thesis, Diponegoro University, Semarang.

3. Levenspiel, O. 1987. Chemical Reaction Engineering, 2nd Ed. John Wiley \& Sons, Inc., New York, pp. 2122.

4. Ministry of Agriculture. 2015. Statistik Konsumsi Pangan 2015. http://epublikasi.setjen.pertanian.go.id/epublikasi/StatistikPertanian/2015/STATISTIK\%20KON SUMSI\%20PANGAN\%202015/files/assets/basic-html/page114.html Accessed 16 October 2018.

5. Naomi, P., A.M. Gaol, and M.Y. Toha. 2013. Pembuatan Sabun Lunak dari Minyak Goreng Bekas Ditinjau dari Kinetika Reaksi Kimia. Journal Teknik Kimia 19(2): 42-48.

6. Nevin, and L. Sweeney. 2013. Soap from waste cooking oil. http://www.underthechokotree.com/index.php?option=com_content\&view=article\&id=305:soap -from-waste-cooking-oil Accessed 14 July 2018.

7. Suriyani, L.D. 2016. Cerita menarik pengolahan jelantah jadi biodiesel di Bali. http://www.mongabay.co.id/2016/09/02/cerita-menarik-pengolahan-jelantah-jadi-biodiesel-dibali Accessed 5 December 2017. 